\title{
Gölpazarı Havzası'nın Kuvaterner Gelişimi (KB Türkiye)
}

\author{
Quaternary Development of the Gölpazarl Basin (NW Turkey)
}

\author{
Esra GÜRBÜZZ1,2, Gürol SEYITTOĞLU ${ }^{1}$ \\ ${ }^{1}$ Ankara Üniversitesi, Mühendislik Fakültesi, Jeoloji Mühendisliği Bölümü, Tektonik Arașttrma Grubu, \\ 06100, Tandoğan, Ankara \\ ${ }^{2}$ Aksaray Üniversitesi, Mühendislik Fakültesi, Jeoloji Mühendisliği Bölümü, 68100, Aksaray \\ (e-posta: egurbuz@aksaray.edu.tr)
}

\section{öz}

Gölpazarı Havzası, Türkiye'nin kuzeybatısında, ideal geometrik özelliklerine rağmen literatürde iyi tanıtılmamış bir çek-ayır havzadır. Tabanı $500 \mathrm{~m}$ kotunda bulunan havza DKD-BGB yönünde $12 \mathrm{~km}$ uzunluğa sahipken en geniş yeri 4.5 km'dir. Sağ yanal doğrultu atımlı Gölpazarı Fayı'na bağlı olarak gelişen havza, KB ve GD kesimlerinde doğrultu atım, KD-GB kenarlarında ise normal karaktere sahip faylarca sınırlanır. Taban seviyesinin GB'ya doğru eğimlenmesi, söz konusu fayların göreceli aktivitelerinin sonucudur. Havza tortulları ve jeomorfolojinin gösterdiği üzere Kuvaterner'in ilk yarılarında kapalı bir çöküntü durumunda olan havzanın güneyinde daha sonra Akçay tarafından bir boğaz açılmış ve havza dış drenaja açık hale gelmiştir. Kalın havza dolgusunun varlığı, havzanın dış drenaja göreceli olarak yakın bir zamanda açılmış olduğuna işaret etmektedir. Havzanın bölgede Kuzey Anadolu Fay Zonu'nun kuzey ve orta kollarının denetiminde gelişen diğer çek-ayır havzalara gerek konumsal gerekse de sağ-yanal doğrultu atımlı rejim altında gelişmiş olması itibariyle yakınlık göstermesi, bu havzanın da kökensel olarak Kuzey Anadolu Fay Zonu'nun makaslama alanı içerisinde gelişmiş olabileceğine işaret etmektedir.

Anahtar Kelimeler: Aktif tektonik, çek-ayır havza, Gölpazarı fayı, Kuzey Anadolu Fay Zonu, morfotektonik

\section{ABSTRACT}

The Gölpazarı basin is a pull-apart basin, that located in the northwestern Turkey, is not well-advertised in literature against its ideal geometric features. The basin floor is located at an altitude of $500 \mathrm{~m}$ with a size of $12 \mathrm{~km}$ in length and $4.5 \mathrm{~km}$ in width in ENE-WSW direction. The basin which has developed related to the right-lateral Gölpazar1 fault, is bounded by strike-slip faults in the NW and SE edges and by normal faults in the NE and $S W$ margins. The basin floor has tilted towards west as a result of the relative activities of these faults. As represented by the basin fill deposits and geomorphology, the Gölpazarı basin was a 
closed depression and then by the opening of a strait in the south of the basin by the Akçay stream, the basin was opened to external drainage in the early Quaternary. The existence of a thick Quaternary sequence indicates that the capturing of the drainage basin by the external drinage has occured relatively young. Because of the close position of the basin to other pull-apart basins that developed under the control of the northern and middle strands of North Anatolian Fault Zone and origination by the right-lateral strike-slip regime have call to mind a genetic origination within the shear zone of the North Anatolian Fault Zone.

Keywords:, Active tectonics, Gölpazarl fault, morphotectonics, the North Anatolian Fault Zone, pullapart basin

\section{GíRiş}

Güneydoğu Marmara bölgesinde, Bilecik ilinin doğusunda bulunan Gölpazarı Havzası literatürde iyi tanıtılmamış bir depolanma alanıdır (Şekil 1). Önceki çalışmalarda çevre jeoloji ve jeomorfolojisi temelinde genel özellikleri esas alınarak karstik çöküntü alanı (örn. Ekmekçi ve Nazik, 2004), ya da normal faylarla sınırlanmış bir graben olarak tanıtılmıştır (örn. Çağlar ve İşseven, 2004; Gürer, 1996). Ancak yapısal özellikleri incelenmemiş olan bu havzanın geometrisi, kuzeyindeki Pamukova ve batısındaki Yenişehir gibi Kuzey Anadolu Fayı'nca denetlenen havzalarının varlığı, Gölpazarı Havzası'nın da doğrultu atımlı faylanmalara bağlı bir çöküntü alanı olabileceğini düşündürmektedir.

Literatürde Gölpazarı Havzası'nın jeolojik evrimine ilişkin ayrıntılı bir inceleme olmamakla beraber, yakın çevresine ait stratigrafinin açıklandığı bazı çalışmalar bulunmaktadır (Abdüsselamoğlu, 1958; Eroskay, 1965; Saner 1977; Y1lmaz vd., 1981). Bunlar havzanın hangi temel kayalar üzerinde geliştiğini göstermeleri bakımından önemlidir. Buna karşın doğrudan Gölpazarı Havzası'na dönük çalışma oldukça azdır ve bunlar tektonik karakteri bağlamında herhangi bir bilgi sunmamaktadır. Gölpazarı Havzası konumu itibariyle Türkiye'nin tektonik olarak en aktif bölgelerinden biri olan Marmara bölgesinde yer alır (Şekil 1). Bu durum birinci derece deprem bölgesi içinde yer alan Gölpazarı Havzası'nın oluşum ve gelişim süreçleriyle daha iyi tanınması gerekliliğini ortaya koymaktadır. Bu eksiklikten hareketle, havzanın tektonik karakterini yapısal ve morfolojik veriler 1şı̆̆ında belirlemek ve KB Anadolu'nun neotektonik çerçevesindeki konumunu tartışmak bu çalışmanın temel amacını oluşturmaktadır.

\section{ÇALIŞMA ALANININ GENEL JEOLOJISİ}

Çalışma alanı ve yakın çevresinin en yaşlı kayaç topluluğu Sakarya Zonu'na ait Paleozoyik yaşlı (Duru vd., 2002) Söğüt metamorfitleridir (Şekil 2). Bunlar, granit ve granitoyid kompleksinden oluşan Karbonifer yaşlı (Çoğulu vd., 1965) Sarıcakaya granitoyidi tarafindan kesilmektedir (Duru vd., 2002). Bu temel kayaçlar, Pontidler ve Anatolid-Torid kuşakları arasında Sakarya Zonu'nun alt seviyelerinde yer alan, Permo-Triyas yaşlı Karakaya grubunu oluşturan Gökçekaya metamorfitleri ve Karatepe formasyonu ile tektonik dokanaklıdır (Gedik ve Aksay, 2002). Permo-Triyas yaşı birimler üzerine uyumsuz olarak Alt Jura yaşıı kırmızı renkli bol fosilli kumtaşlarından oluşan Bayırköy formasyonu gelmektedir. Bayırköy formasyonu üzerinde Üst Jura-Alt Kretase yaşlı Soğukçam formasyonu ve Bilecik kireçtaşları bulunur. Bilecik kireçtaşları, Geç Jura'da bir neritik karbonat alanı olan Sakarya kıtasının karakteristik ürünleridir (Altınlı, 
1973; Saner, 1977; Yılmaz, 1981; Şengör ve Y1lmaz, 1981). Erken Kretase'de ise ortamın hızla derinleştiği çörtlü kireçtaşlarının varlığından anlaşılmaktadır. Bu litolojiler üzerine Üst KretasePaleosen yaşlı yamaç-havza çökellerinden oluşan ve üst seviyelerinde sığlaşan bir denizel ortamı temsil eden genel olarak grimsi, yeşil renkli marn ve beyaz, bej, kırmızı, pembe renkli, ince tabakalı mikritik kireçtaşı ile az miktarda konglomeradan oluşan Yenipazar formasyonu gelir (Duru vd., 2002). Formasyon üste doğru farklı lokasyonlarda resifal kireçtaşlarından oluşan Selvipınar (Alt Paleosen) ile karasal çökellerden oluşan Kızılçay (Paleosen) formasyonları sı̆̆ denizel ortam ürünlerini içeren Çataltepe (Alt Eosen) ve Halidiye (Orta Eosen) formasyonlariyla geçişlidir. Karbonat, kiltaşı, şeyl ve kumtaşı litolojisinden oluşan Halidiye formasyonu üzerine konglomera, kumtaşı, çamurtaşı ve kiraçtaşı içeren
Gemiciköy formasyonu (üst Eosen- Alt Miyosen) uyumsuzlukla gelmiştir (Gedik ve Aksay, 2002). Halidiye formasyonuyla paralel uyumsuzluk gösteren birim, üstte havza dolgusunu temsil eden Kuvaterner yaşlı birimler tarafindan açısal uyumsuzlukla örtülür.

\section{YAPISAL JEOLOJI}

Gölpazarı Havzası bulunduğu konum nedeniyle kuzeyde Kuzey Anadolu Fay Zonu ve güneyde Eskişehir Fay Zonu gibi Türkiye'nin önemli doğrultu atımlı fay zonları arasında kalan dikkate değer bir alandır (Şekil 1). Havza doğrultu atımlı sistemlerin doğal bir sonucu olarak oluşmuş olup, doğrultu atımlı faylar ve bunlara diyagonal şekilde gelişen normal faylarla sınırlanır (Önde ve Gürbüz, 2010; Şekil 3).

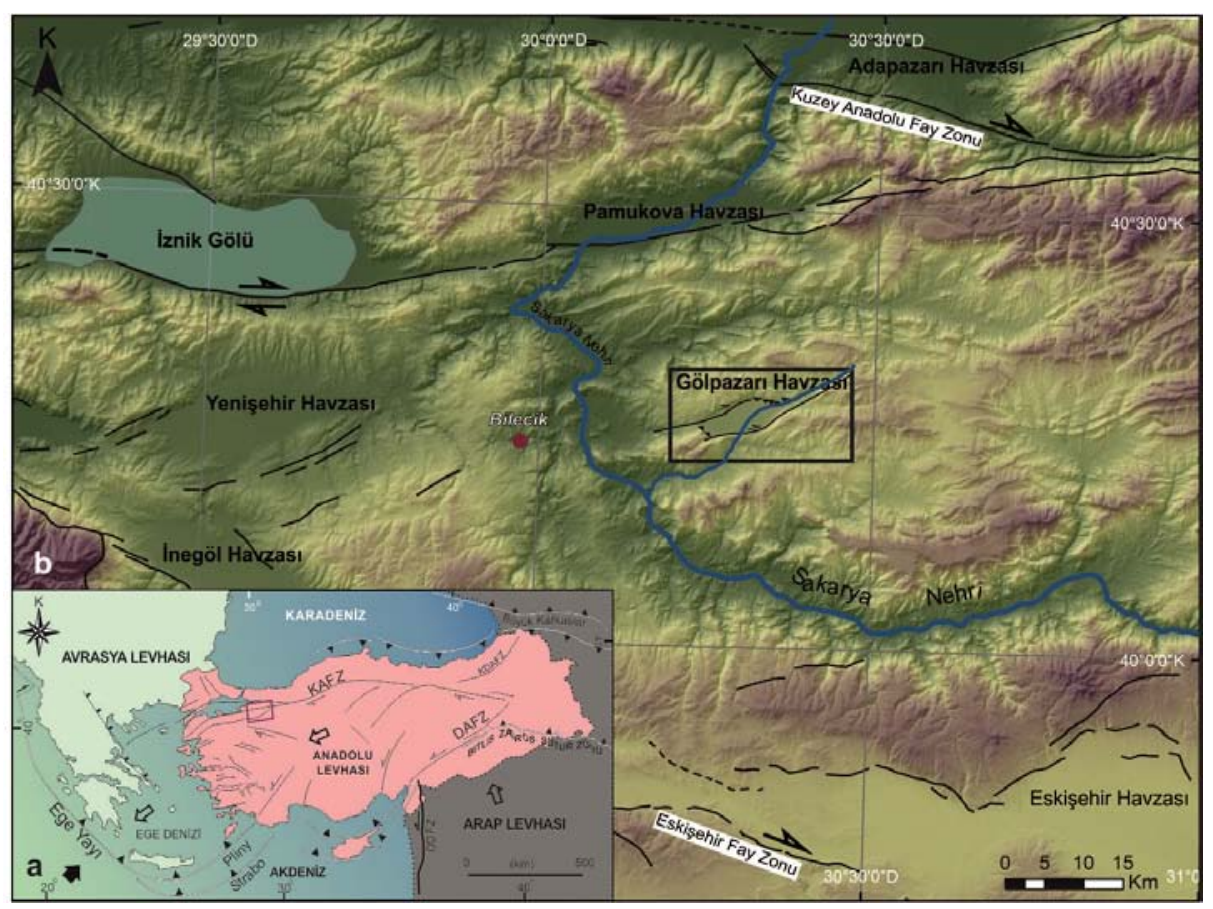

Şekil 1. A) Türkiye ve yakın çevresinin başlıca tektonik yapıları (Gürbüz ve Gürer, 2008). B) Çalışma alanına ait yer bulduru haritası (Faylar Emre vd. 2013'den sadeleştirilerek alınmıştır).

Figure 1. A) Major tectonic structures of Turkey and surroundings (Gürbüz and Gürer, 2008). B) Location map of the study area (simplified from Emre et al., 2013). 


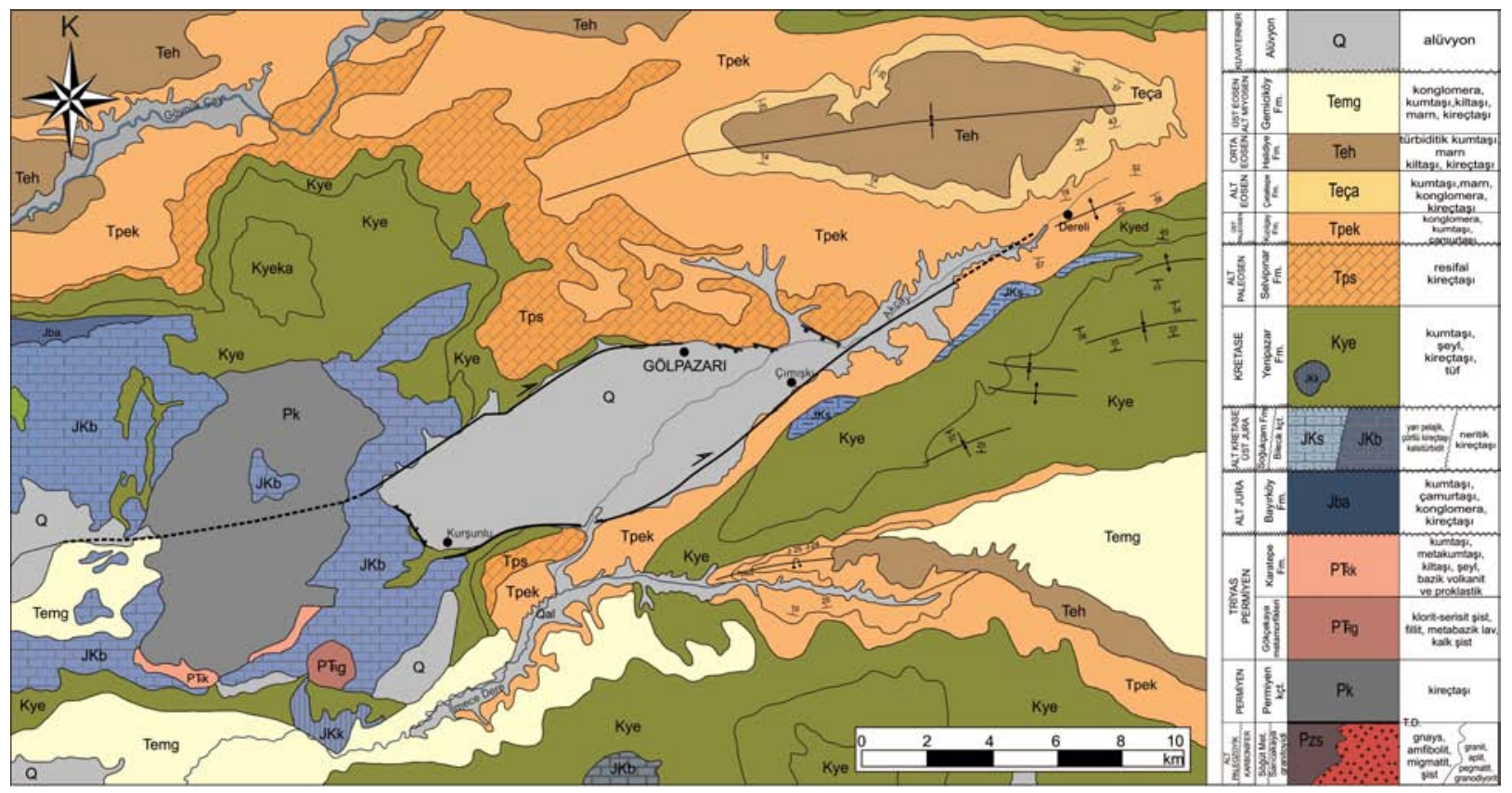

Şekil 2. Çalışma alanı ve çevresinin jeoloji haritası (Duru vd. 2002'den değiştirilerek alınmıştır. Haritadaki kıvrım eksen verileri Tuncer, 2004'ten alınmıştır).

Figure 2. Geological map of the study area and surrounding (modified from Duru et al., 2002. Fold axis data from Tuncer, 2004).

Gölpazarı Havzası'nın oluşumuna sebep olan să̆ yönlü doğrultu atımlı fay, bu çalışma kapsamında Gölpazarı Fayı olarak adlandırılmıştır. Gölpazarı Fayı KD'da Dereli mevkinin kuzeydoğusundan başlayıp GB'da Hüyük yerleşkesine kadar 35 km'lik bir uzanıma sahiptir. Fay havzaya girdiği KD kesiminden itibaren çalışma kapsamında iki segment olarak incelenmiş olup bunlardan havzanın güney kesimini sınırlayan KD-GB gidişli KurşunluDereli segmenti, kuzey kesimini sinırlayan ise Gölpazar1-Hüyük segmenti olarak adlandırılmıştır. Arazi çalışmaları sırasında bu fay segmentlerine ait düzlemlerin kayma yüzeyleri ve kayma çizikleri incelenmiştir. Elde edilen kinematik veriler FaultKin 7 programinda (Marrett ve Allmendinger, 1990; Allmendinger vd. 2012) analiz edilerek yorumlamaları yapılmıştır.

Genel doğrultusu DKD-BGB ile D-B olan Kurşunlu-Dereli segmenti havza güneyinde belirgin sarplıklar sunar (Şekil 4). Söz konusu sarplıklar herhangi bir drenaj şebekesi tarafından henüz kesilmemiş durumdadır. KurşunluDereli segmenti, Kurşunlu Köyü civarında Üst Kretase yaşlı birimleri kesmekte ve sağ yanal özellikteki kinematik karakterini açık bir şekilde sergilemektedir (Şekil 5). Havza güneyinde yer alan Kurşunlu ve Çımışkı Köyleri arasında, Üst Kretase kireçtaşlarına ait blok ve çakıllardan oluşan farklı büyüklüklerde birikinti konileri bulunmaktadır. Bunlara ilişkin gözlemler havza dolgusu kısmında verilmiştir.

Gölpazarı Fayı'nın, Gölpazarı Havzası'nı kuzeybatıdan sinırlayan segmenti, Gölpazar1Hüyük segmenti olarak adlandırılmıştır (Şekil 3, 6). Gölpazar1-Hüyük segmenti, KurşunluDereli segmentine yaklaşık koşut şekilde DKDBGB ile D-B yönünde uzanım göstermektedir. Gölpazarı ilçesi bu segmentin önünde kurulmuş olup, fay sarplıkları ve düzlemleri Kurşunlu- 
Dereli segmentine nispeten daha az korunmuş olmakla beraber bu kesimde de sağ yanal hareket sunmaktadır (Şekil 7).

Çek-ayır havzalarda doğrultu atımlı faylar arasında kalan bloğun uçlarında meydana gelen zit yönlü hareket bu hareket yönlerine yaklaşık verev fayların gelişmesine sebep olur (örn. Crowell, 1974). (Şekil 3). Havzanın kuzeydoğu ve güneybatısını sınırlayan faylar, çek-ayır havzaların oluşumunda faaliyet gösteren doğrultu atımlı faylar arasında kalan çöküntünün uç kısımlarını sınırlayan normal faylardır (Şekil 8, 9). Havzanın kuzeydoğusunu sınırlayan normal faylar KB-GD gidişlidir. Bu kesimdeki faylara paralel/yarı-paralel şekilde uzanan havza güneybatısındaki normal faylı kesimde belirgin üçgen yüzeyler dikkat çekmektedir. Ancak toprak örtüsü nedeniyle bu alanlarda başka bir kinematik veriye rastlanmamıştır.

Bahsi geçen neotektonik dönem yapılarının haricinde çalışma alanının doğu ve kuzeydoğusunda paleotektonik döneme ait kıvrımlar mevcuttur. Eosen ve büyük bölümü Kretase yaşlı birimlerde gözlenen bu kıvrımlara ait eksenler yaklaşık K-G yönlü bir sıkışma fazının varlığına işaret etmektedir (Şekil 2).

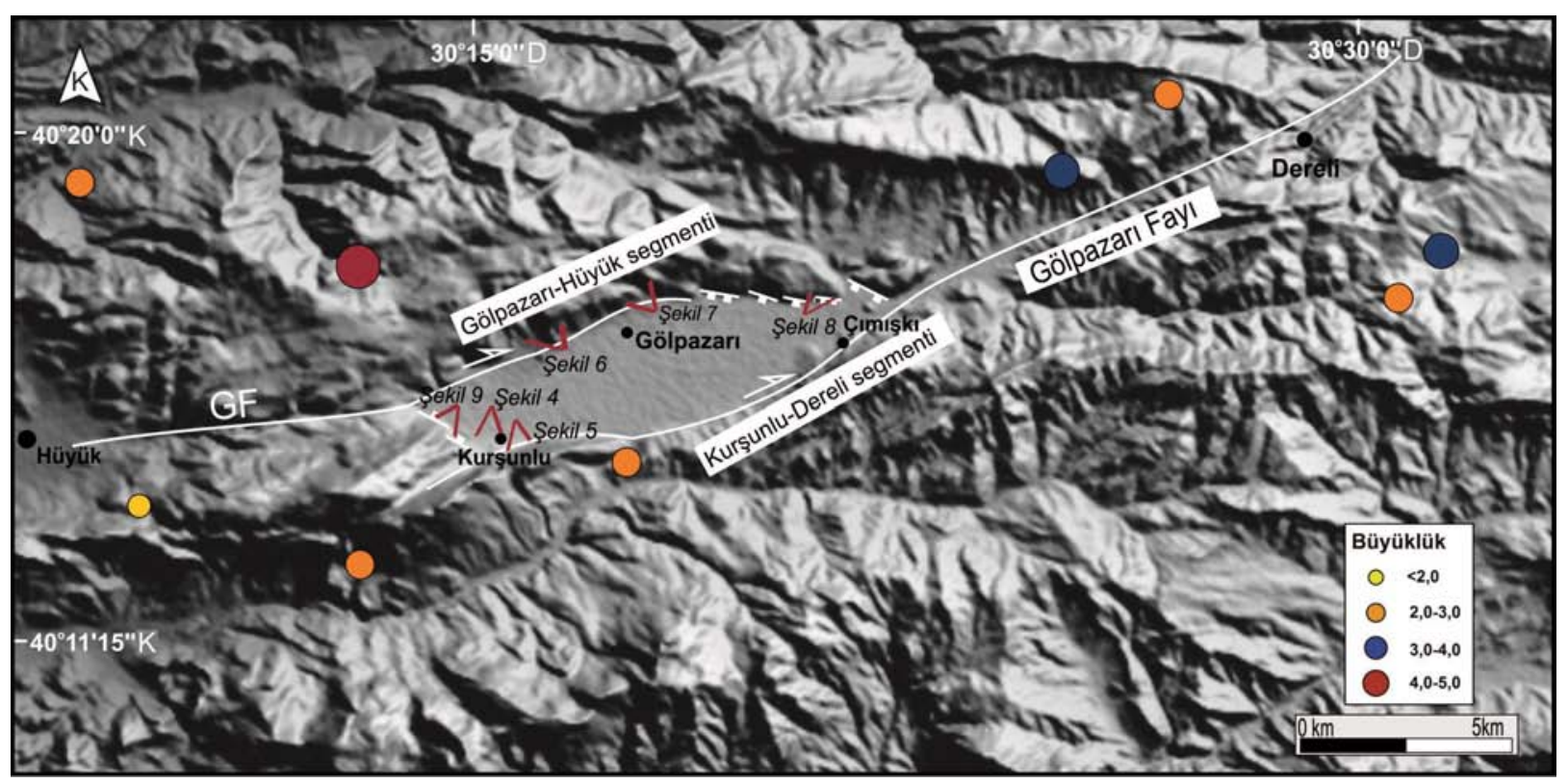

Şekil 3. Gölpazarı Havzası'nı denetleyen faylar ve havza civarının depremselliği (Deprem verileri AFAD ve KOERİ'den alınmıştır).

Figure 3. Faults controlled the Gölpazari Basin and the seismicity around the basin (Eartquake data from AFAD and KOERI). 


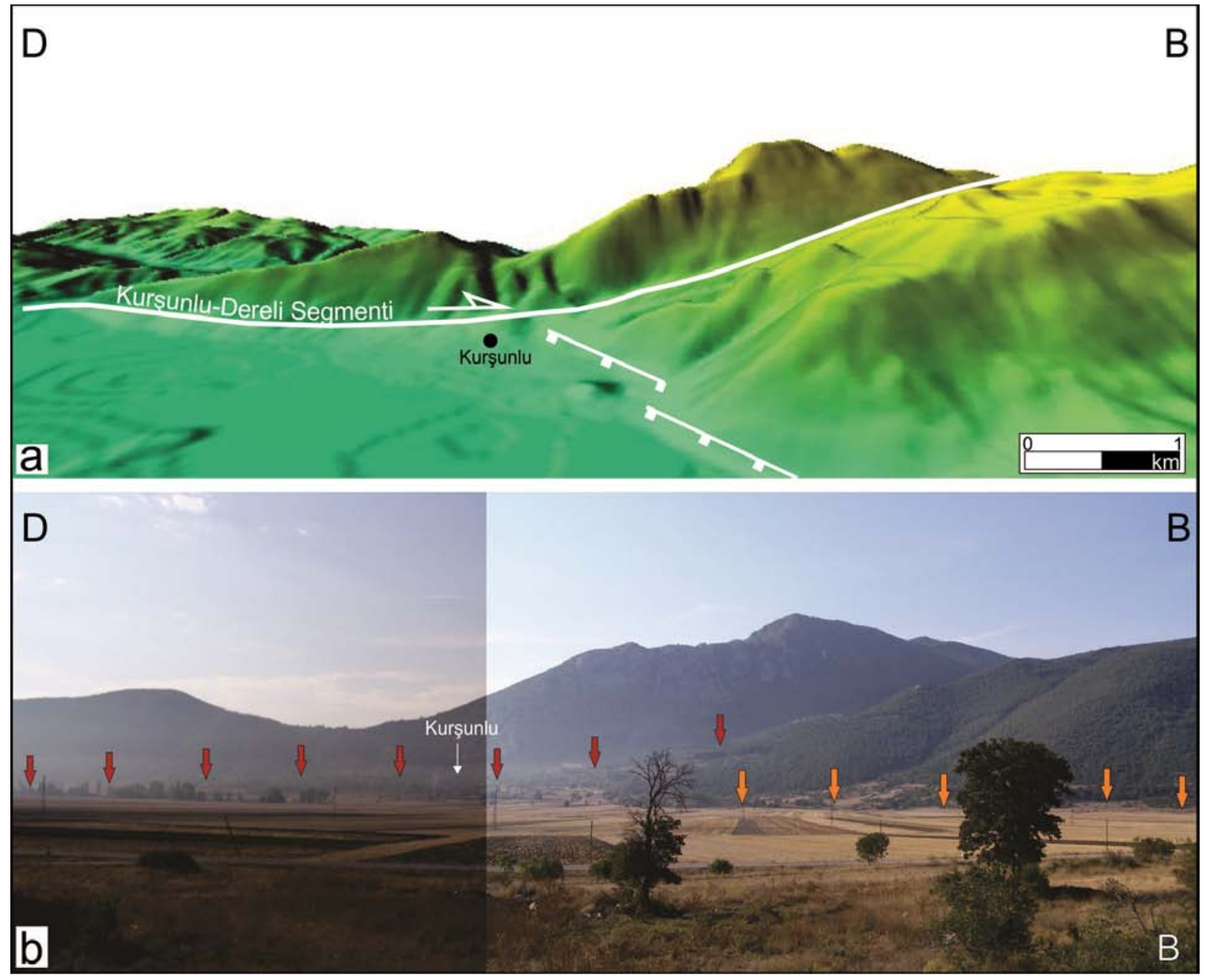

Şekil 4. A) Kurşunlu-Dereli segmentinin Kurşunlu köyü civarındaki konumunu gösteren Sayısal Yükseklik Modeli (düşey abartı x2). B) Aynı alanın arazi görüntüsü (Kuzey’den bakış).

Figure 4. A) DEM image that indicates the position of the Kurşunlu-Dereli segment around the Kurşunlu village (vertical exaggeration $x 2$ ) B) Terrain image of the same location (view from north).

\section{MORFOTEKTONIK}

54 km²’lik Gölpazarı havzasını barındıran, 170 $\mathrm{km}^{2}$ 'lik beslenme havzası içerisindeki ana akarsu, KD-GB doğrultulu uzanan Akçay'dır. Çalışma alanında gelişen akaçlama ağı dentritik tip drenaj olup, havzanın doğu ve kuzeydoğusunda iyi gelişmiştir (Şekil 10). Sağ yanal doğrultu atımlı faylanmayla ilgili akarsularda gözlenen ötelenmelerin başında havzayı kateden Akçay'ın
\% km'lik atımı gelirken, bunun haricinde havzanın kuzeyinde Kocaemin Deresi'nde yaklaşık 1,5 km să yanal ötelenme gözlenmektedir (Şekil 10). Pleyistosen'de kapalı bir havza durumunda olan Gölpazarı Havzası daha sonra Sakarya Nehri'nin havza güneyindeki boğazı geriye doğru aşındırmasıyla dış drenaja açılmış ve Akçay, Sakarya Nehri tarafindan kapılmıştır. Bunun sonucunda havzanın batı kesiminde, havza tabanın en derin bölgesinde önceden yer 
alan eski Gölovası gölü büyük ölçüde drene olmaya başlamış ve havza tabanındaki alüvyonlar yarılmıştır. Havzada gözlenen fay sarplıklarının yeni bir drenaj sistemiyle kesilmemiş olması, mevcut drenaj sisteminin henüz havza içlerine ilerlememiş olması, havzanın oluşumunda etken olan fayların aktif olduğunu ve gölün yakın bir zamanda dış drenaja açılması nedeniyle bu alanda yeni bir drenaj sistemi gelişecek kadar vakit geçmemiş olduğunu göstermektedir.

Çek-ayır havzalar derin, çoğunlukla romboidal şekilli çöküntüler olup, iki yanlarından yarı paralel doğrultu atımlı faylar tarafından sinırlanırlar (örn. Crowell 1974). Faylanma mekanizmasından dolayı havzaların uç kesimlerinde, yani doğrultu atımlı fayları kesen kenarlarda deformasyonun ilerleyen aşamasında normal faylar gelişir. Diğer taraftan kazanılan bu eğim atım bileşeni sayesinde sıçrama yapan doğrultu atımlı fayların havza içerisine bakan yüzeyleri boyunca eğim atım bileşeni de etkili olmaya başlar. Bu da ana karakteri doğrultu atım olan faylar arasında kalan alanın çökmesine sebep olur. Çalışma alanında bu çökmenin gözlenebilmesi için havzayı sınırlayan fayları keser şekilde topografik profiller alınmıştır (Şekil 11). Hazırlanan sayısal yükseklik modeli ve alınan kesitlerde dikkat çeken en önemli husus havza kenarları ile havza tabanının yüksek açılarla birleşmesidir. Bunlardan KP3 ve KP4 GölpazarıHüyük segmentine, KP5-KP10 Kurşunlu-Dereli segmentine, KP1 ve KP2 ise havzanın KD'sunu sınırlayan normal fayın doğrultusuna dik olarak alınmıştır. Diğer kenar profillerinden farklı olarak KP4 profilinde, düzlük olarak gözükmesi beklenen alan, eğimli ve diğer profillerin alt seviyelerinden yüksek kotta görülmektedir. Bunun nedeni bu alanda meydana gelen heyelan sonucu taşınan malzemenin eğimin azaldı ̆̆ 1 alanda birikmiş olmasıdır. Buna ek olarak KP7 ve KP8 profillerinde ki kademeli yapı bu bölümdeki eski faylanmalara işaret etmektedir. KP9 ve KP10 profillerinin alındığı yüzeyler ise belirgin üçgen yüzeyler olup, KP7 ve KP8'de gözlenen genç fayın bu hat boyunca devam ettiğini göstermektedir. Yüksek açılı havza kenar morfolojisi ile çalışma alanı ve yakın çevresinde hâkim litolojinin kireçtaşı olması bu alanda karstlaşma etkisini düşündürmektedir. Önceki çalışmalarda havzanın gelişimi ile ilgili olarak bölgede karstlaşmaya bağlı çökme olduğundan bahsedilirken (örn. Ekmekçi ve Nazik 2004), diğer bir çalışmada ise Gölpazarı Havzası karstik olmayan alan olarak haritalanmıştır (Tuncer, 2004). Bu çalışmada yapmış olduğumuz gözlemlerimize göre ise, karstlaşmanın havza kenarındaki bazı birimlerde etkili olduğu fakat bunun Gölpazarı havzasının açılmasında doğrudan bir etken olamayacağı yönündedir. En önemli karstlaşma izlerine Jura-Alt Kretase yaşlı Bilecik kireçtaşlarında rastlanmaktadır. Birimin özellikle havzanın batısında kalan Hüyük bölümünde karstik yapılar oluşturduğu görülmüştür. Bununla beraber havzanın KB sınırını oluşturan ve Bilecik kireçtaşlarından oluşan Sipahi Dağı'nda topoğrafyanın da etkisiyle karstik etki azalmış, dağın havzaya bakan kısımlarında faylanmanın etkisiyle sarp yamaçlar oluşmuştur. Çalışma alanında karstik etkinin görüldüğü bir diğer birim resifal kireçtaşlarından oluşan Selvipınar formasyonudur (Şekil 12). Özellikle havza KD sınırının ardında kalan bölümde birim içinde yatay yönde gelişim göstermiş karstik boşluklar mevcuttur. Boşlukların yatay yönde gelişmesi, bu alanda karst taban düzeyinin morfolojik taban düzeyinden yüksekte olmasıyla açıklanmıştır (Tuncer, 2004). 


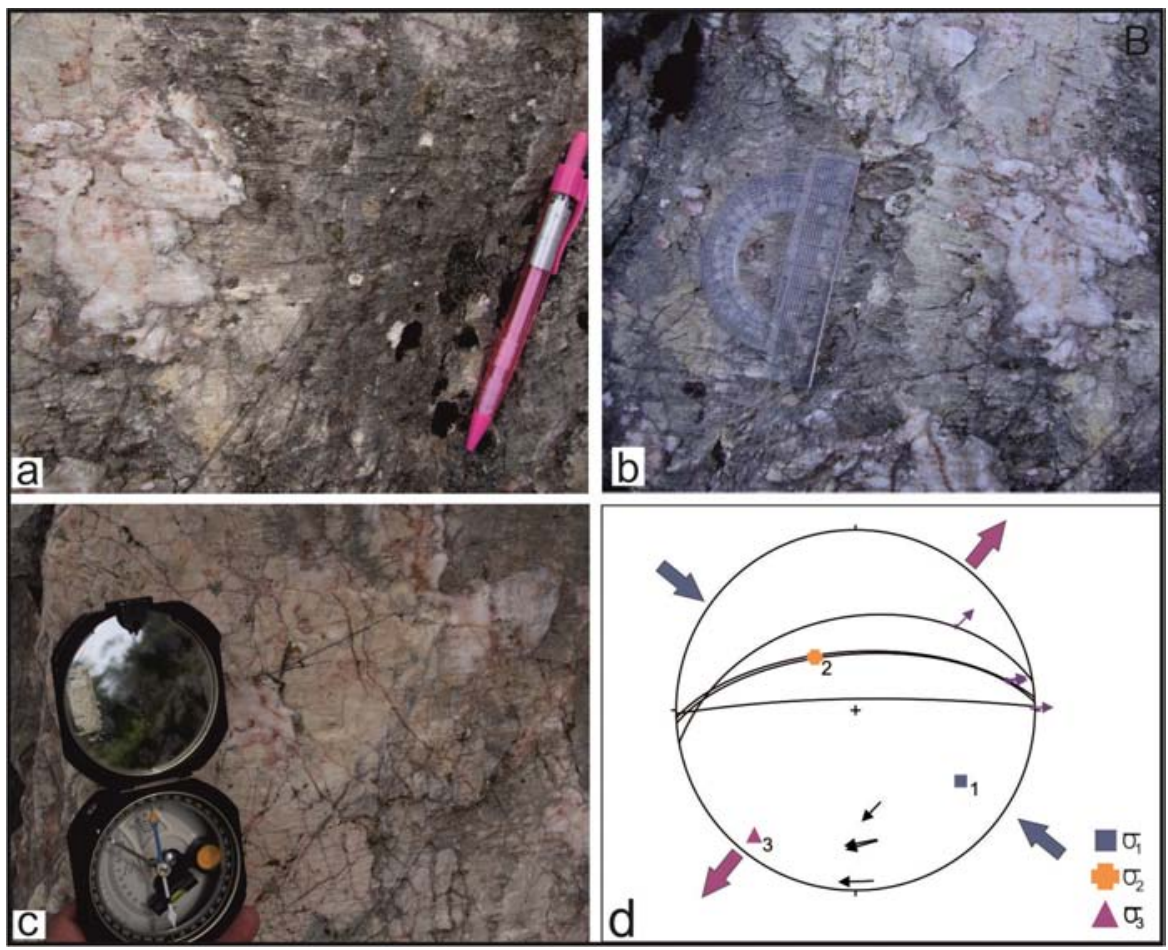

Şekil 5. Kurşunlu-Dereli segmentinin Yenipazar formasyonu içerisinde gözlenen fay düzlemlerine ait kinematik veriler.

Figure 5. Fault planes and kinematic data related to the Kurşunlu-Dereli segment observed in the Yenipazar formation.

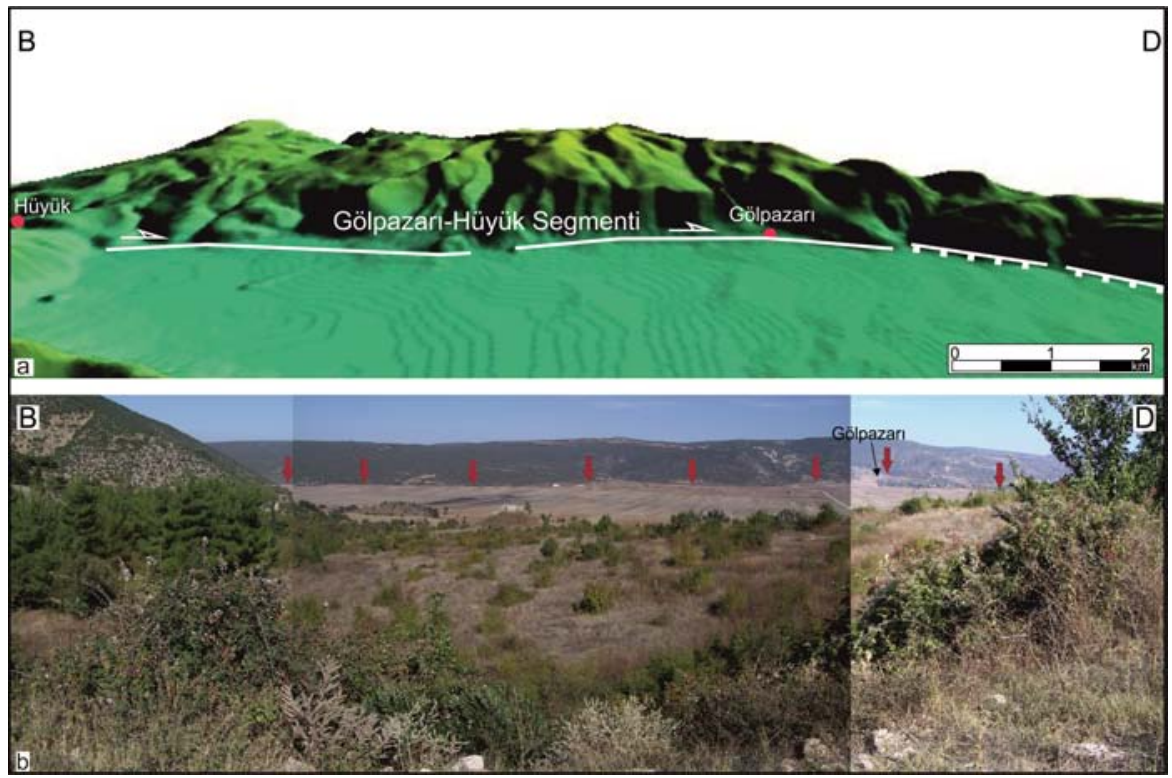

Şekil 6. A) Havza kuzeyini sınırlayan Gölpazarı-Hüyük segmentine ait Sayısal Yükseklik Modeli. B) Aynı alanın arazi görüntüsü (Güney’den bakış).

Figure 6. A) DEM image the Golpazari-Hüyük segment that bounds the northern margin of the basin B) Terrain image of the same location (view from south). 

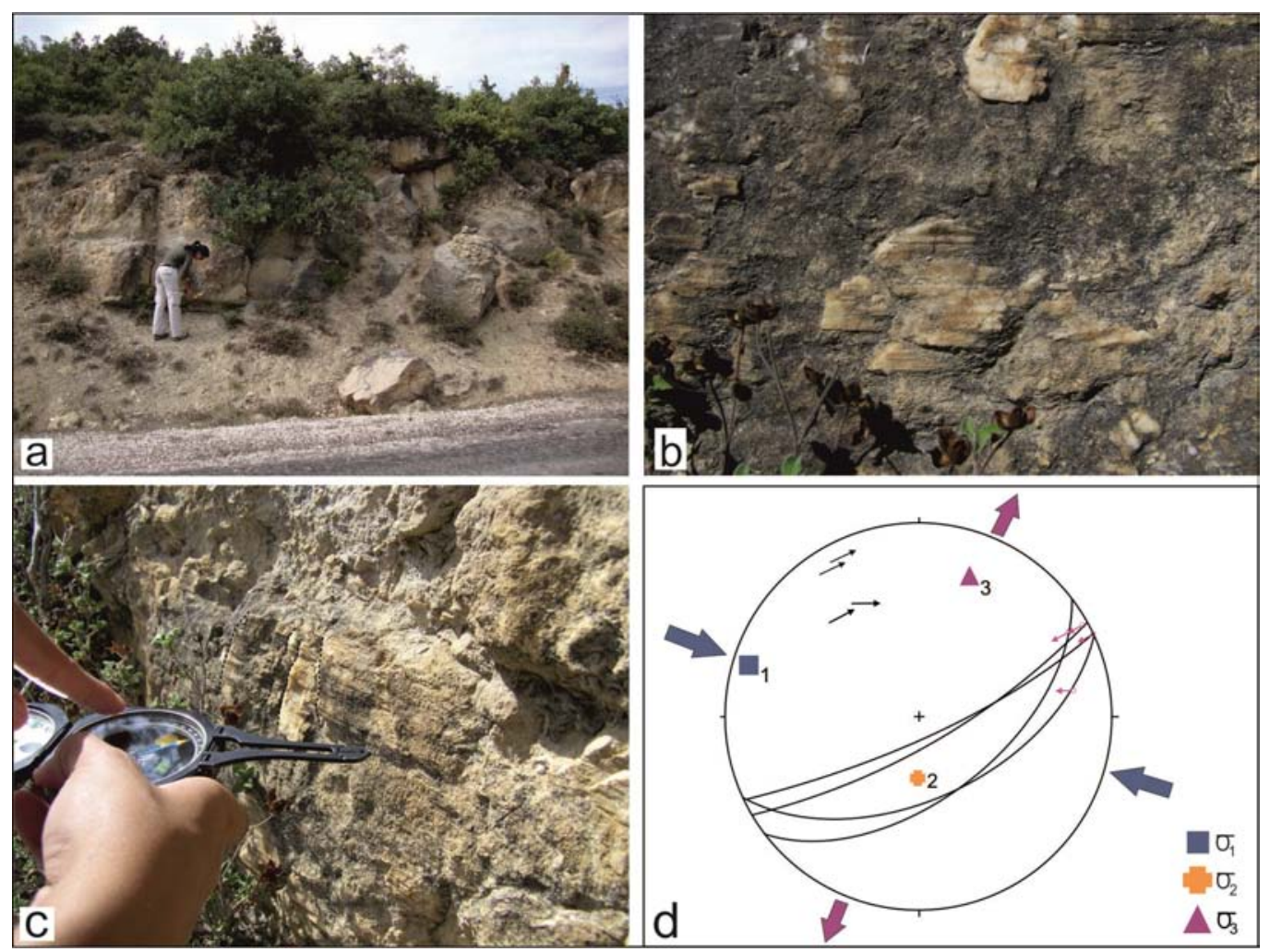

Şekil 7. Gölpazarı-Hüyük segmentinin Selvipınar formasyonu içerisinde gözlenen fay düzlemleri ve fay çiziklerine ait stereonet diyagramı.

Figure 7. Fault planes and kinematic data related to the Gölpazari-Hüyük segment observed in the Selvipinar formation.

Havza tabanı üzerinde tektoniğin etkisini anlamak üzere alınan iki adet profilden TP1 havzanın uzun eksenine paralel, diğer bir profil ise buna dik konumdadır (Şekil 11). Havzanın güney kenarı morfolojik olarak daha yüksek olmasına rağmen, uzun eksene dik alınan TP2 profilinde ise tabanda ciddi bir eğimlenme görülmemektedir. TP1 profilinde, ortalama yükseltisi 500-550m kadar olan havza tabanının genel eğiminin GB doğrultusunda olduğu açıkça görülmektedir (Şekil 11). DSİ tarafından 1974'te Gölpazarı havzası içerisinde yapılan jeofizik rezistivite etüdünde
300-500 m derinliğe inebilen 90 noktadan ölçüm alınmıştır (Şekil 10). Rezistivite ölçülerinden hazırlanan havza kesitleri de yüzeydeki gözlemleri destekler niteliktedir (Şekil 13).

1963 yılına kadar sı̆̆ bir göl (Gölovası Gölü) bulunan bu alana doğu eğim oldukça azdır (\%0.1). Eldeki sondaj loglarının değerlendirilmesi sonucunda gölün daha önceki zamanlarda havzada daha geniş bir alan işgal ettiği, zamanla çekilerek 1963 yılında DSİ tarafindan kurutulmadan önceki konumunu aldığı anlaşılmaktadır. 


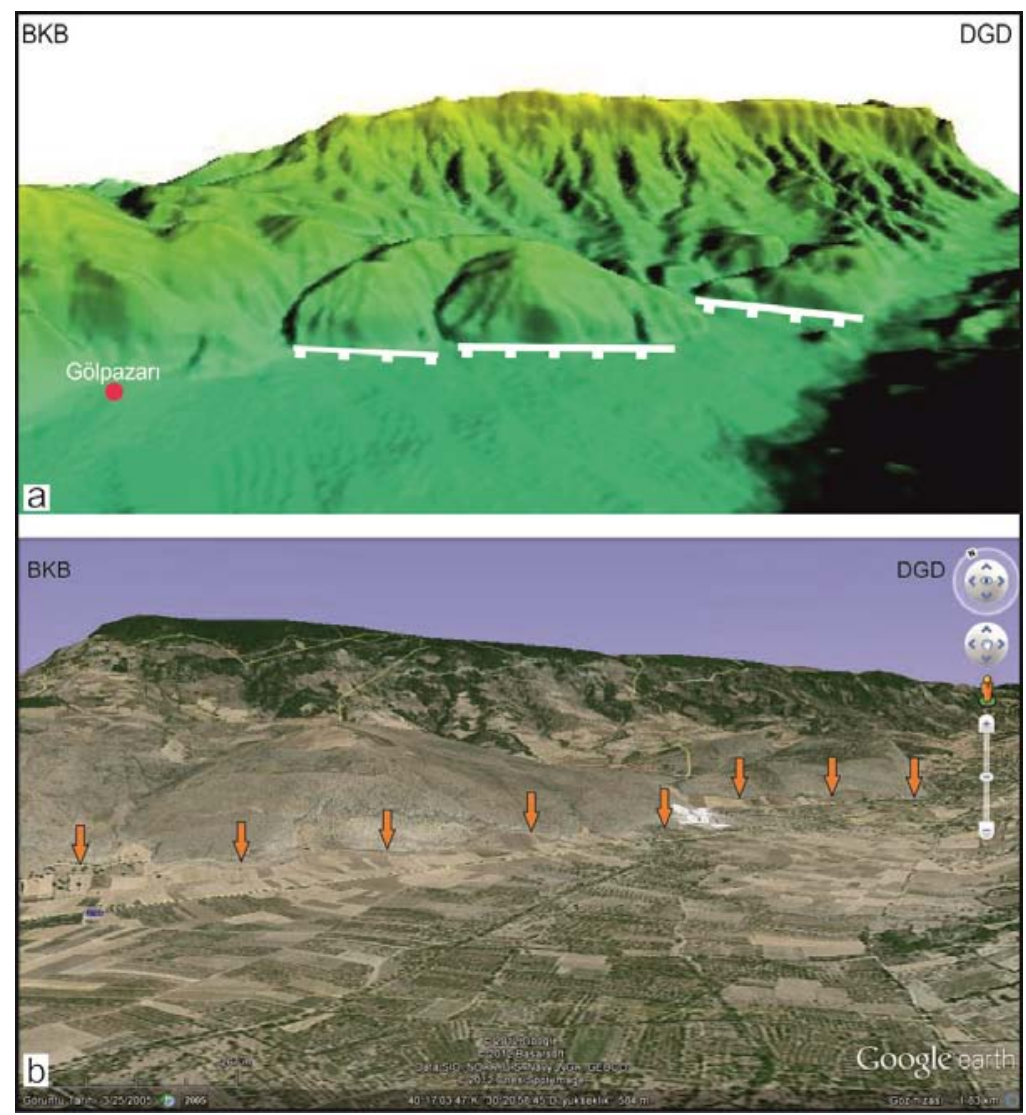

Şekil 8. A) Havza kuzeydoğusunu sınırlayan normal fayın konumunu gösteren Sayısal Yükseklik Modeli B) Aynı alanın Google Earth görüntüsü (düşey abartı x3) (GB'dan bakış).

Figure 8. A) DEM image of the normal fault bounds the northestern margin of the basin B) Google Earth image of the same location (vertical exaggeration $x 3$ ) (view from southwest).

\section{HAVZA DOLGUSU}

Yukarıda da belirtildiği üzere Gölpazarı Havzası doğrultu atımlı ve normal faylarla sınırlı bir çöküntü alanıdır. Literatürdeki pek çok çekayır havza gibi Gölpazarı Havzası da belirli bir kenar morfolojisine ve buna bağlı olarak gelişen kenar tortullarına sahiptir (Şekil 14). Arazi çalışmalarında gözlenen alüvyal ve birikinti yelpazeleri gibi depolanma alanları fayların aktivitesini belirgin şekilde ortaya koymaktadır.
Havzanın güneyini sınırlayan yükseltilerin önlerinde yamaç molozlarından oluşan irili ufaklı birikinti konileri bulunmaktadır. Özellikle Kurşunlu ile Çımışkı Köyleri arasında tane bileşenleri Üst Jura-Alt Kretase yaşl1 karbonatlı ve Paleosen yaşlı kırıntılı kayaçlardan oluşan yamaç molozları gözlenmektedir (Şekil 14).

Gölpazarı Havzası içerisinde DSI tarafından değişik yıllarda yapılan 9 adet sondaja ait loglar yorumlanmıştır (Şekil 10, 15). 


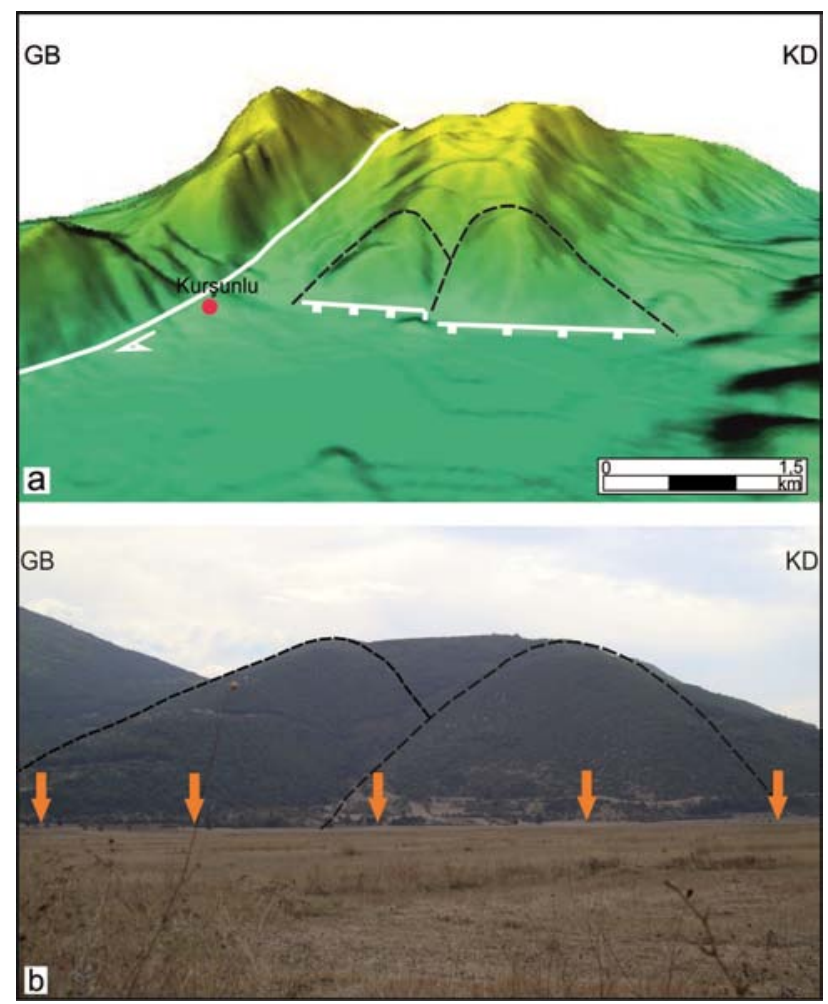

Şekil 9. A) Havza güneybatısını sınırlayan normal fayın Sayısal Yükseklik Modeli (düşey abartı x2). B) Aynı alanın arazi görüntüsü (D'dan bakış).

Figure 9. A) DEM image the normal fault bounds the southwestern margin of the basin (vertical exaggeration x2) B) Google Earth image of the same location (view from east).

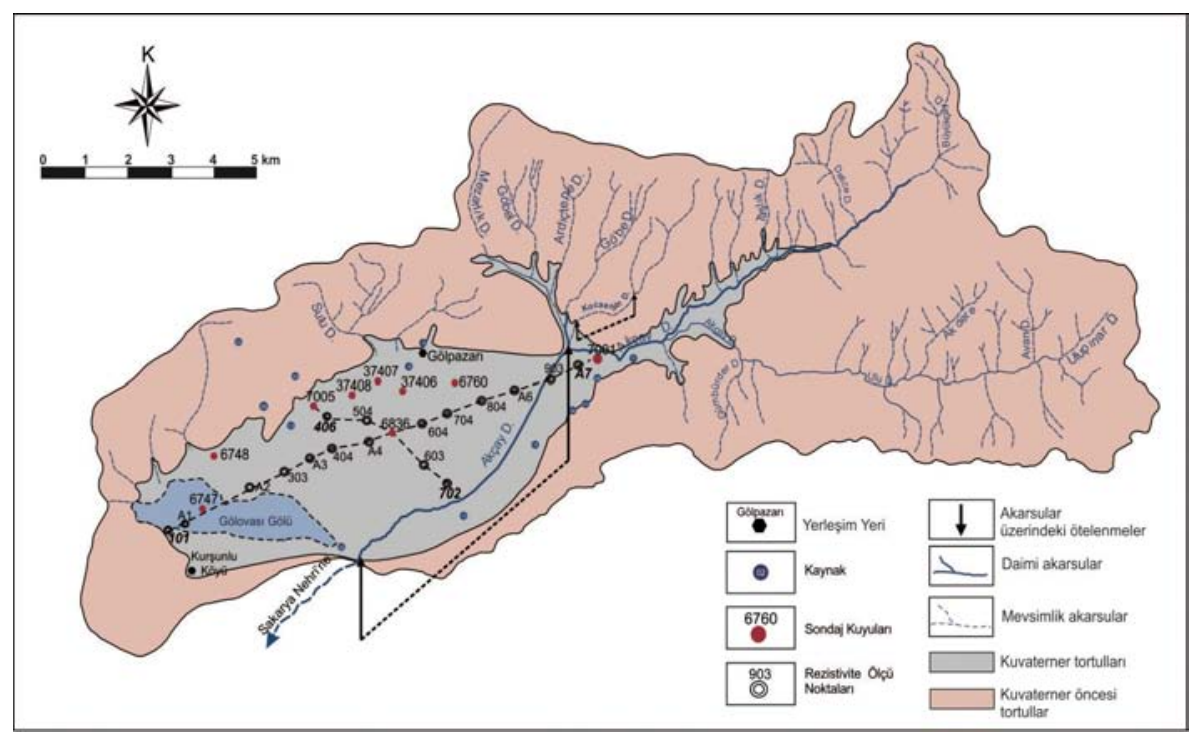

Şekil 10. Gölpazarı Havzası ve yakın çevresinin drenaj haritası ile havzada yapılmış sondajların ve rezistivite ölçüm noktalarının yerleri (DSİ 1974’ten değiştirilerek alınmıştır).

Figure 10. Drainage map of the Gölpazarı basin and surrounding area, and locations of the borehole and resistivity points (modified from DSI, 1974). 


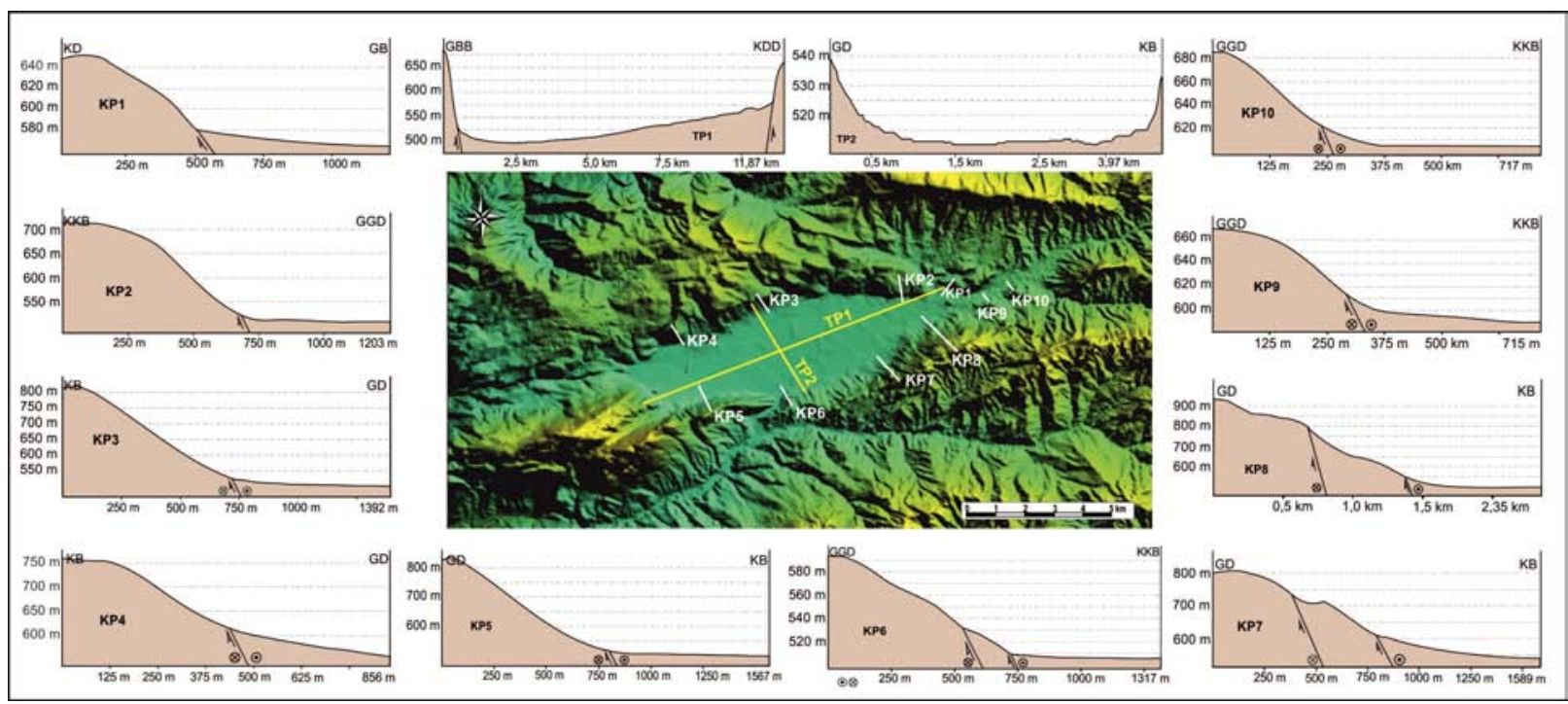

Şekil 11. Gölpazarı Havzası'nın kenarları ve tabanı boyunca alınmış topografik profiller.

Figure 11. Topographical profiles along the basin margins and basin floor.

Bölgede yapılan sondajlar 50-280 m arasında olup, bunlardan havzanın kuzey kenarında yer alan üç tanesi (37406, 37407, 37408) temel birimleri 50 ve 100 m'lerde kesmiştir. Havzanın güney yarısında kalan ve havzada yapılmış en derin sondajda ise 280 m'de dahi temele girilememiştir (Şekil 15). Havza içerisindeki istif tamamen Kuvaterner yaşlı alüvyonlardan oluşsa da havza doğusu ve batısı arasında bir takım hidrografik farklılıklar görülmektedir. Gölpazarı yerleşkesi ile Akçay'ın havzayı terk ettiği boğaz referans alınarak çizilen yaklaşık K-G doğrultulu bir hattın doğusundaki çökeller genel olarak kum ve çakıl bileşenlidir. Buna bağlı olarak da önemli miktarda yeraltı suyu içerirler. Ancak hattın batısında ise killi malzeme hâkimdir ve yer altı suyu içermemektedir (DSİ, 1974).

Sondaj loglarında verilen litolojiler dikkate alınarak başlıca 8 litofasiyes ayırtlanmıştır (Tablo 1). Bu fasiyeslerin loglardaki dağılımı belirli gruplanmalar göstermektedir. Genellikle çakı1, killi çak11, killi kumlu çakıl ve kumlu çakıl kendi arasında bir fasiyes birliği oluşturmuştur. Birinci fasiyes topluluğu (FT1) kum-çak11 egemen, kaba taneli malzemeden oluşur ve havza kenarı tortullarını teşkil eder. Bunlar büyük olasılıkla küçük alüvyon yelpazeleri ve bunların gerisindeki birikinti konileridir. Yeşil ve bej renkli killer ikinci bir fasiyes topluluğudur (FT2). Killerin açık ve koyu renkli oluşları dikkat çeker. FT2 su içinde çökelmeyi dolayısıyla göl ortamını temsil eder. Koyu renk (yeşil) genellikle organik maddeden ve/veya kil içindeki demirin oksitlenmesinden ileri gelir. Her iki durumda da durgun, hızlı, yenilenmeyen göreceli olarak derin su ortamlarını işaret eder (Cohen, 2003). İkinci fasiyes topluluğunun açık renkli killeri büyük olasılıkla göl ortamının dış drenaja açıldığı, tatlı sulu göl olduğu dönemleri temsil eder (örn. Cohen, 2003). Buna göre jeolojik zaman içerisinde eski Gölovası gölünün derinleştiği ve sığlaştığı veya açık ve kapalı hale geldiği göl konumları olmuştur. Sondajlarda belirlenen göl istifinin üçüncü bölümü killi kum ve kumun oluşturduğu 'kumlu fasiyes topluluğu'dur. Bunlar çoğunlukla istifin 
en üst düzeylerinde bulunurlar. Bu üçüncü fasiyes topluluğu (FT3), büyük olasılıkla gölün ortadan kalktığı ve akarsu ortamının oluştuğu dönemi temsil etmektedir. Genel olarak bakıldığında FT1, FT2 ve FT3 fasiyes topluluklarıyla yanal geçişlidir. Havza kenarı ve havza ortası alanı işaret eder. FT2 ise FT3 topluluğu tarafından örtülmektedir. Yani önce derin olan göl zamanla sığlaşmış, ardından göl ortadan kalkarak, yerine akarsuların hâkim olduğu 'ova' durumu egemen hale gelmiştir. $\mathrm{Bu}$ durum giderek sığlaşan ve kapanan bir göl havzasını göstermektedir.

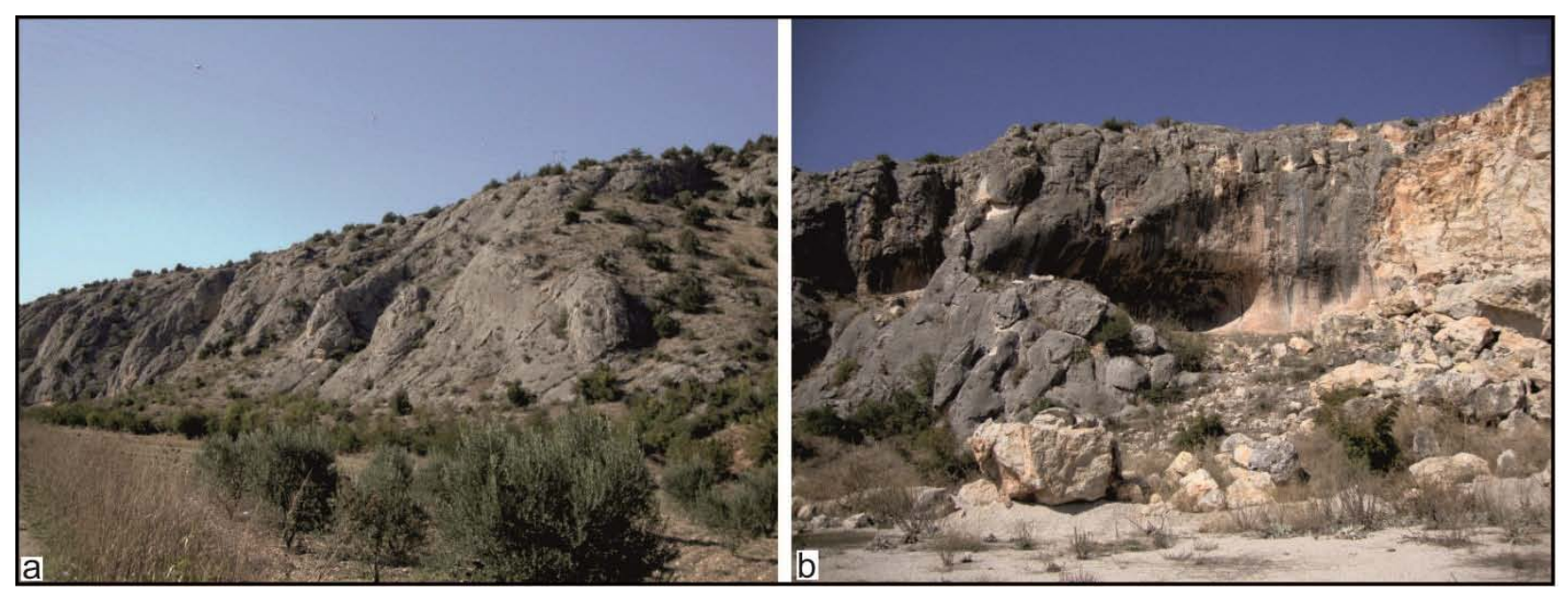

Şekil 12. Havza kuzeydoğusunda yer alan fay sarplıkları ve bu alanda gözlenen karstik yapılar.

Figure 12. Fault scarps located in the northeast of the basin and observed karstic structures in this area.

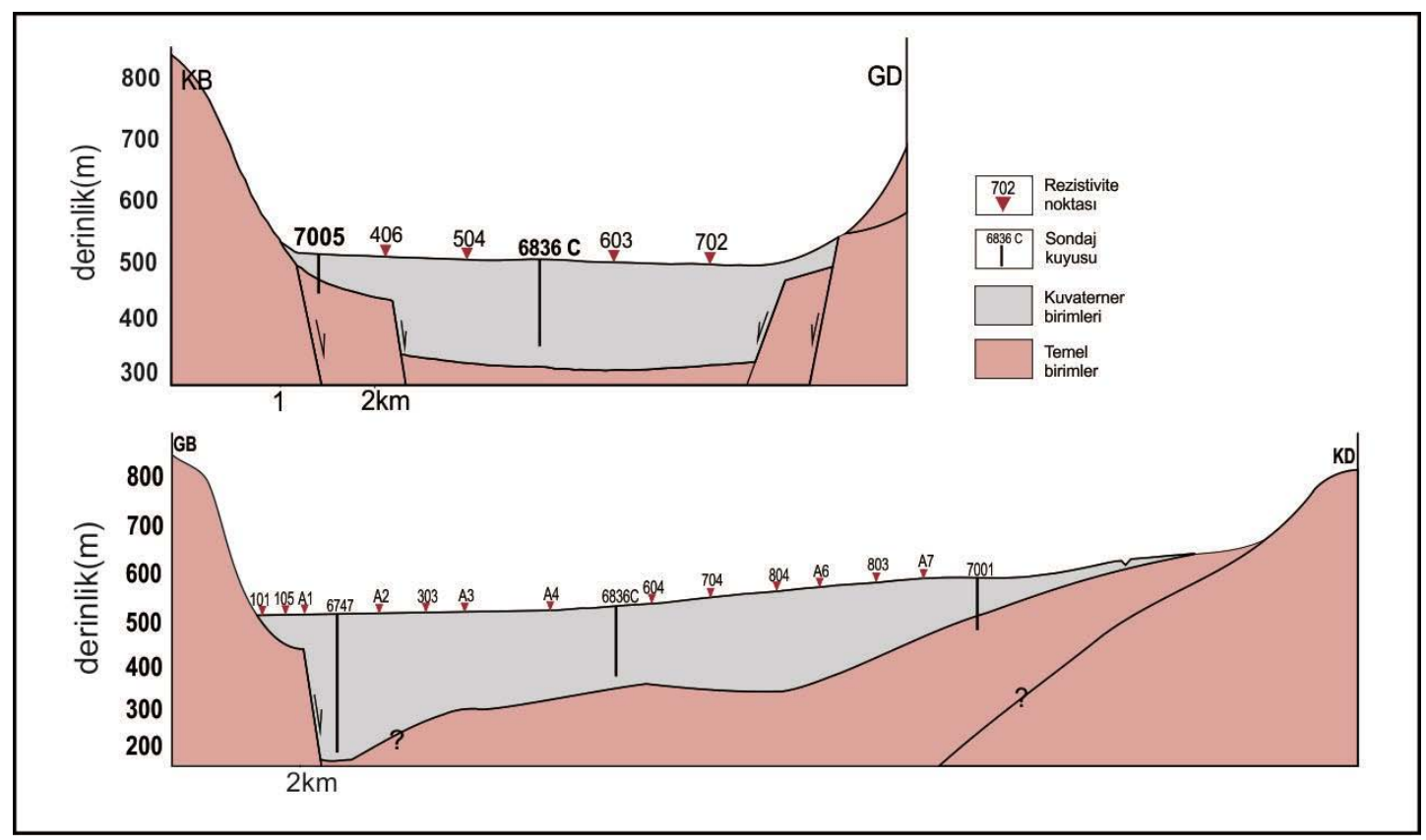

Şekil 13. Gölpazarı Havzası'nın rezistivite verilerine göre hazırlanmış kesitleri (DSİ, 1974; kesit hatları için Şekil 10'a bakiniz).

Figure 13. Geological sections of the Gölpazarı basin according to resistivity data (DSI, 1974; please look at Figure 10 for section lines). 


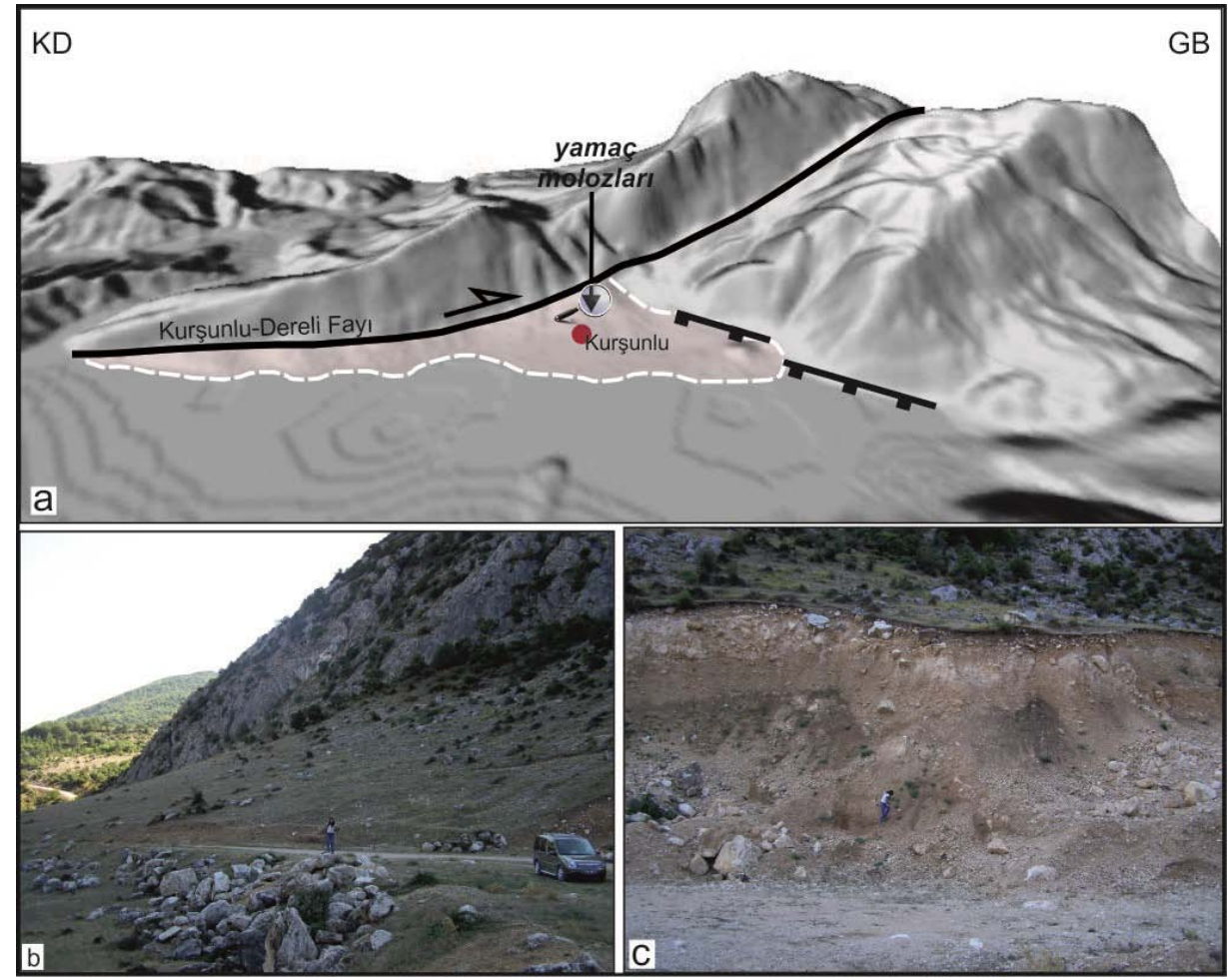

Şekil 14. A) Kurşunlu köyü civarında yamaç molozlarının kapladığı alanı gösteren Sayısal Yükseklik Modeli B ve C) Kurşunlu mevkinde bulunan yamaç molozları

Figure 14. A) DEM image presents the talus covered area around the Kurşunlu village. $\boldsymbol{B}$ and $\mathbf{C})$ Talus deposits around Kurşunlu village.

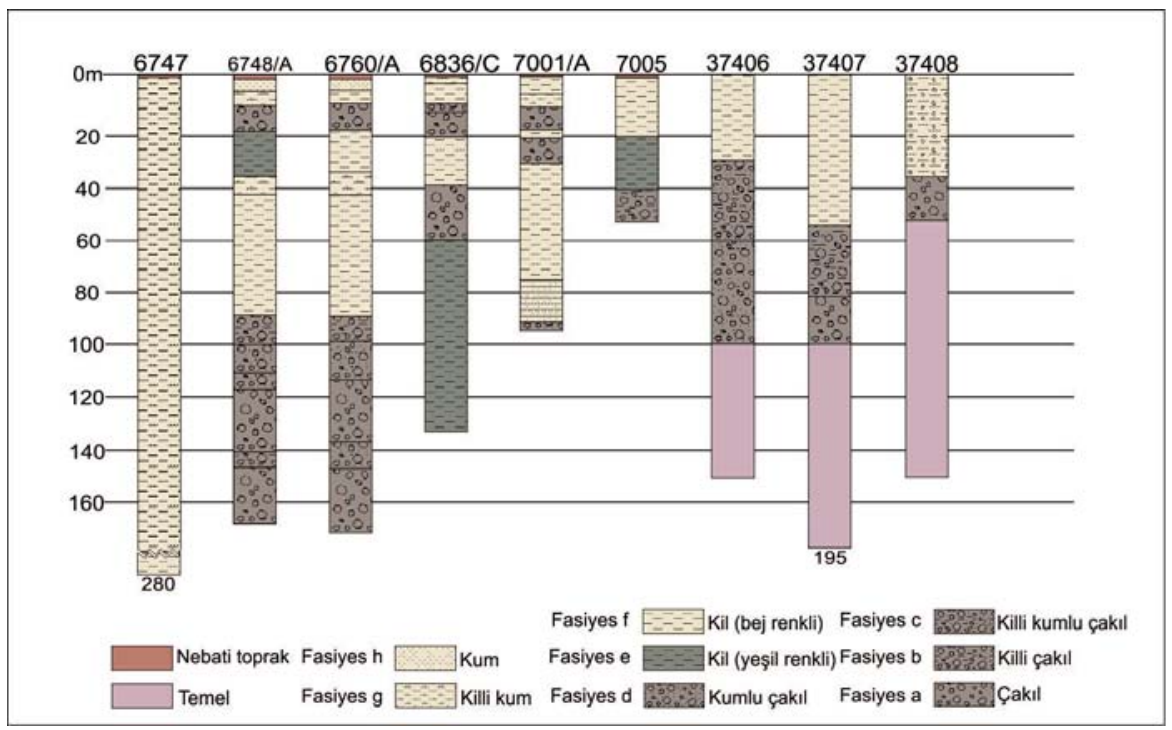

Şekil 15. Gölpazarı Havzası'nda yapılmış sondajlara ait loglar (DSİ 1974'ten değiştirilerek alınmıştır, sondaj yerleri için Şekil 10'a bakınız).

Figure 15. Logs of boreholes that drilled in the Gölpazar1 Basin (modified from DSI, 1974; please look at Figure 10 for borehole locations). 
Çizelge 1. Havza totullarına ait fasiyes özellikleri.

Table 1. Facies characteristics of basin deposits.

\begin{tabular}{|c|c|c|c|c|}
\hline $\begin{array}{l}\text { Fasiyes } \\
\text { Toplulukları }\end{array}$ & Fasiyes & Litoloji & Özellikler & Ortamsal Yorum \\
\hline \multirow{4}{*}{ FT1 } & Fasiyes $a$ & Çakı1 & \multirow{4}{*}{$\begin{array}{l}\text { Tutturulmamış ve/veya } \\
\text { az tutturulmuş kaba taneli } \\
\text { malzeme. Köşeli ve az } \\
\text { yuvarlanmış. Çimento ve } \\
\text { tane destekli. }\end{array}$} & \multirow{4}{*}{$\begin{array}{l}\text { Alüvyal yelpaze ve yamaç } \\
\text { molozları. Havza kenar } \\
\text { tortullarını temsil eder. }\end{array}$} \\
\hline & Fasiyes $b$ & Killi çakıl & & \\
\hline & Fasiyes c & Killi kumlu çakıl & & \\
\hline & Fasiyes $d$ & Kumlu çakıll & & \\
\hline \multirow{2}{*}{ FT2 } & Fasiyes e & Yeşil kil & \multirow{2}{*}{$\begin{array}{l}\text { Yeşil kesimler plastik } \\
\text { özellikte. }\end{array}$} & \multirow{2}{*}{$\begin{array}{l}\text { Siğ ve göreli derin gölsel } \\
\text { çökeller. }\end{array}$} \\
\hline & Fasiyes $f$ & Bej renkli kil & & \\
\hline \multirow[t]{2}{*}{ FT3 } & Fasiyes $g$ & Killi kum & \multirow{2}{*}{$\begin{array}{l}\text { Akçay'ın getirdiği } \\
\text { malzemelerce temsil olan } \\
\text { orta, kaba kum. Yer yer kil } \\
\text { içermekte. }\end{array}$} & \multirow[t]{2}{*}{ Flüviyal tortullar. } \\
\hline & Fasiyes $h$ & Kum & & \\
\hline
\end{tabular}

\section{TARTIŞMA VE SONUÇLAR}

Hiç kuşkusuz KB Anadolu'da en etkin tektonik yapıyı Kuzey Anadolu Fayı ve kolları oluşturmaktadır. Kuzey Anadolu Fayı, Bolu yakınlarında kollara ayrılır ve çok sayıda Kuvaterner yaşlı havza oluşturur. Bu bağlamda Gölpazarı Havzası'nın Bolu tarafında üç kola ayrılan KAFZ'ın güney kolu üzerinde yer aldığı önerilmektedir (Seyitoğlu ve diğ. değerlendirmede).

Gölpazarı Havzası'nda ve kenar kesimlerinde Neojen'e ait herhangi bir tektonik kontrollü çökel birimi gözlenememiştir. Bölgeye Geç Pliyosen'de yerleşen Sakarya Nehri'nin (Emre ve diğ. 1998) Gölpazarı Havzası'na ait Akçay'1 kapabilmesi ancak bu dönemden sonra gerçekleşmiş olmalıdır. Bu da havzanın oluşum yaşının Sakarya Nehri'nin bölgeye yerleşiminden sonra, ancak Akçay'ın dış drenajca kapılmasından önce olmasını gerektirir.

Ölçeksel olarak ele alındığında Gölpazarı Havzası bölgedeki diğer çek-ayır havzalara göre daha küçüktür $\left(54 \mathrm{~km}^{2}\right)$. Örneğin bölgedeki diğer yakın havzalardan Yenişehir Havzası 186 km², Pamukova Havzası 102 km² yüzey alanına sahiptir.
Söz konusu havzaların oluşum yaşları için Geç Pliyosen yaşı önerilmiştir (Koçyiğit 1988; Gürbüz ve Gürer 2008, Gürbüz, 2010). Çek-ayır havzalarla ilgili literatürdeki çalışmalar, bu ve benzeri havzaların evrimlerinin ilerleyen aşamalarında, havza kesen faylarca biçildikleri zamana dek büyüdüklerini göstermektedir (bkz. Rahe ve diğ., 1998; Gürbüz ve Gürer, 2009). Bölgede Gölpazar1 havzasına boyutca en yakın olan havza Sapanca Gölü çek-ayır havzasıdır $\left(\sim 60 \mathrm{~km}^{2}\right)$ ve bu havza da Orta Pleyistosen'de gelişmiştir (Gürbüz ve Gürer, 2008). Tüm bunlar dikkate alındığında Gölpazarı Havzası'nın oluşumu için önerilebilecek en uygun yaş Erken-Orta Pleyistosen'dir.

Gölpazarı Havzası, açılımı ile birlikte giderek derinleşen bir göl ortamı haline gelmiş ve bu süre boyunca özelikle kuzeydoğu kesiminden hızlı ve fazla tortul almıştır. Göl Pleyistosen'de hızlı tortul alımıyla beraber, tatlı sulu ve dış drenaja açık hale gelmiştir. Göreceli olarak küçük bir havzada oldukça hızlı gelişen tortul alımı ve biriken kalın istif tektonik faaliyeti işaret etmektedir. Büyük olasılıkla Orta-Geç Holosen'de havzanın göl niteliği ortadan kalkmış ve akarsuova rejimi halini almıştır. 


\section{KATKI BELIRTME}

Buçalışmabirinciyazarın, ikinciyazardanışmanlığ kapsamında Ankara Üniversitesi Fen Bilimleri Enstitüsü'nde tamamlamış olduğu yüksek lisans tez çalışmasının bir kısmını içermektedir. Yazarlar çalışmanın gerçekleştirilmesinde, ikinci yazarın yurtdışında bulunduğu süreçte tez danışmanlığını üstlenen ve sedimantolojik incelemeler konusunda bilgilerini paylaşan Nizamettin Kazancı'ya, ayrıca görüş ve önerileriyle tez çalışmasına katkı sağlayan Bülent Kaypak, Mustafa Ergin, Korhan Esat, Sinan Akıska, Ayşe Çağlayan ve Alper Gürbüz'e teşekkür ederler.

\section{EXTENDED SUMMARY}

The Gölpazarl basin is a pull-apart structure that located in northwestern Turkey, is not welladvertised in literature in contrast to its ideal geometric features. The basin floor is situated at an altitude of $500 \mathrm{~m}$ with a size of $12 \mathrm{~km}$ in length and $4.5 \mathrm{~km}$ in width in an ENE-WSW direction. The basin has been developed as a natural result of strike-slip tectonics and bounded by diagonal normal faults as well as right lateral strike-slip faults. In this study, the right lateral strike-slip fault that caused the development of the Gölpazart basin has been denominated as the Gölpazarl fault. The Gölpazarl fault extends at a length of $\sim 35 \mathrm{~km}$ between Dereli village to the northwest and Hüyük village to the southwest. The fault is investigated under two segments; the NE-SW trending Kurşunlu-Dereli segment which bounds from the southern margin of the basin, and the parallel directed Gölpazart-Hüyük segment along the northern margin of the basin. The northeastern and southwestern basin bounding faults represent by normal faults which are located in the both ends of pull-apart basin development process. The main stream that flows within $170 \mathrm{~km}^{2}$ of drainage basin, which includes the $54 \mathrm{~km}^{2}$ of Gölpazarl basin, is the NE-SE trending Akçay stream. As a result of strike-slip faulting, some deflections have been observed along the primary and secondary streams of the basin. Topographic profiles that distributed in basinwide have been analysed to understand the effects of tectonic activity along the basin margins and on basin floor. The Gölpazarl basin have a definite margin morphology and consequently developed basin margin deposits like almost of all pull-apart basins in literature. Within the scope of our study, facies characteristics of these basin margin deposits and basin infill have been analysed and interpreted. According to our geomophological and sedimentological observations, the likeliest age that can be suggested for the development of the Gölpazarı basin is Early-Middle Pleistocene. As determined from the facies analysis, the Gölpazart basin was a deepening lacustrine environment in the initial stages of development. During this period, the basin fed by big amounts of sediment particularly from the northeastern portion. Due to rapid inflling process in Pleistocene, this lacustrine environment had become a freshwater basin and opened to external drainage. This quite fast evolving sediment recharge and deposited thick sequence in such a relatively small-scaled basin indicate relatively high amounts of tectonic activity. Probably, the lacustrine environment of the basin disappeared in Middle-Late Holocene, and the basin turned into current fluvial-plain regime.

\section{DEĞINILEN BELGELER}

Abdülselamoğlu, M.Ş., 1958. Göynük-Gölpazarı bölgesinde denizel Miyosen var mi?, MTA Raporu, No: 2674

Allmendinger, R. W., Cardozo, N. C., ve Fisher, D., 2012. Structural Geology Algorithms: Vectors \& Tensors: Cambridge, England, Cambridge University Press, 289 pp. 
Altınlı, İ.E., 1973. Orta Sakaryanın Jeolojisi. 50. Y1l Yerbilimleri kongresi, Tebliğler Dergisi, MTA Yay., s. 159-187.

Cohen, A.S., 2003. Paleolimnology : The History And Evolution Of Lake Systems/Andrew S. Cohen Oxford ; New York : Oxford University Press, c2003.

Crowell, J.C., 1974. Origin of late Cenozoic basins in southern California, in Dickinson, W.R., ed., Tectonics and Sedimentation: Society of Economic Paleontologists and Mineralogists (SEPM) Special Publication 22, p. 190-204.

Çağlar, İ. ve İşseven T. 2004. Two-dimensional geoelectrical structure of the Göynük geothermal area, northwest Anatolia, Turkey. Journal of Volcanology and Geothermal Research 134, 183- 197.

Çoğulu, H. E., Delaloye, M. ve chessex, R., 1965, Sur 1' age de Quelques roches plutoniques acides dans la region d'Eskişehir- Turquie: Arch. Sci. Geneve, v. 18, p. 692699.

DSİ, 1974. Gölpazarı Ovası Hidrojeolojik Etüt Raporu. Ankara, s. 18

Duru, M., Gedik, İ. ve Aksay, A. 2002. MTA Genel Müdürlüğü, 1:100 000 ölçekli Türkiye Jeoloji Haritaları Serisi, Adapazarı-H24 Paftası, No:37, MTA Jeoloji Etütleri Dairesi, Ankara.

Ekmekçi, M. ve Nazik, L. 2004. Evolution of Gölpazarı-Huyuk karst system (Bilecik-Turkey): Indications of morpho-tectonic controls. Int. J. Speleol., 33 (1/4), 49-64.

Emre, Ö., Erkal, T., Tchepalyga, A., Kazanc1, N., Keçer, M. ve Ünay, E. 1998. Doğu Marmara bölgesinin NeojenKuaternerdeki evrimi. Maden Tetk. Arama Derg., No. 120, pp. 289-314.

Emre, Ö., Duman, T.Y., Özalp, S., Elmacı, H., Olgun ve Şaroğlu, F., 2013. Türkiye Diri Fay Haritası. Maden Tetkik ve Arama Genel Müdürlüğü, Özel Yayın Serisi-30. Ankara-Türkiye.

Eroskay, S.O., 1965. Paşalar Boğazı-Gölpazarı Sahasının jeolojisi. İstanbul Üniversitesi Fen Fakültesi Mecmuas1, Seri: B, Cilt: XXX, Sayı:3-4, s. 135-170.

Gedik, İ. ve Aksay, A., 2002. MTA Genel Müdürlüğü, 1:100.000 ölçekli Türkiye Jeoloji Haritaları Serisi, Adapazarı-H25 Paftas1, No: 38, MTA Jeoloji Etütleri Dairesi, Ankara

Gürbüz, A. ve Gürer, Ö. F., 2008. Tectonic geomorphology of the North Anatolian Fault Zone in the Lake Sapanca Basin (Eastern Marmara Region, Turkey). Geosciences Journal 12(3), 215-225.

Gürbüz, A. ve Gürer, Ö. F., 2009. Middle Pleistocene extinction process of pull-apart basins along the North Anatolian Fault Zone. Physics of the Earth and Planetary Interiors, 173, 177-180.
Gürbüz, A., 2010. Geometric characteristics of pull-apart basins. Lithosphere 2 (3), 199-206.

Koçyiğit, A., 1988. Tectonic setting of the Geyve basin: age and total displacement of Geyve fault zone, METU Pure Appl. Sci., 21, pp. 81-104.

Marrett, R. A., ve Allmendinger, R. W., 1990. Kinematic analysis of fault-slip data: Journal of Structural Geology, v. 12, p. $973-986$

Önde, E. ve Gürbüz, A., 2010. Morphotectonic setting of the Gölpazari pull-apart basin: Implications on the region between the North Anatolian and Eskişehir fault zones, NW Turkey. Geophysical Research Abstracts Vol. 12, EGU 2010-944-2.

Saner, S., 1977. Geyve-Osmaneli-Gölpazarı-Taraklı alanının jeolojisi; Eski çökelme alanları ve çökelmenin evrimi. MTA Raporu, No: 6306 (İstanbul Üniversitesi Tatb. Jeo. Kürsüsü, Doktora Tezi).

Seyitoğlu, G., Kaypak, B., Aktuğ, B., Gürbüz, E., Esat, K. ve Gürbüz, A. An alternative route for the southern branch of North Anatolian Fault Zone, NW Turkey. Değerlendirmede.

Şengör, A.M.C. ve Yılmaz, Y., 1981. Tethyan Evolution of Turkey: A Plate Tectonic Approach, Tectonophysics, 75, 181-241.

Tuncer, K., 2004. Sakarya Nehri-Göynük Çayı Çatak Çayı Arasındaki Sahanın Karst Jeomorfolojisi, 258 s., İstanbul Üniversitesi, Sosyal Bilimler Enstitüsü, İstanbul.

Yılmaz, Y., 1981. Atlantik tip bir kıta kenarının Pasifik tip bir kıta kenarına dönüşümüne Türkiye'den örnek: Türkiye Jeoloji Kurultayı Konf. Ser., 27.

Yılmaz, Y., Yiğitbaş, E.J., Tüysüz, O. ve Gözübol, A.M., 1981. Abant (Bolu)-Dokurcun (Sakarya) arasında kalan KAF zonunun kuzey vegüneyinde kalan tektonik birliklerin jeolojik evrimi. MTA Raporu, No.7085.

$\begin{array}{ll}\text { Makale Geliş Tarihi } & : \text { 18 Aralık } 2013 \\ \text { Kabul Tarihi } & : 3 \text { Şubat } 2014 \\ \text { Received } & : \text { 18 December } 2013 \\ \text { Accepted } & : 3 \text { February } 2014\end{array}$

